Revue européenne des sciences sociales

European Journal of Social Sciences

XLV-136 | 2007

Démocratie délibérative, démocratie débattante, démocratie participative

\title{
Institutional reform and democratic legitimacy: deliberative democracy and transnational constitutionalism
}

James Bohman

\section{(2) OpenEdition}

\section{Journals}

Electronic version

URL: http://journals.openedition.org/ress/90

DOI: $10.4000 /$ ress.90

ISSN: 1663-4446

Publisher

Librairie Droz

Printed version

Date of publication: 1 February 2007

Number of pages: $95-110$

ISBN: 978-2-600-01114-3

ISSN: 0048-8046

\section{Electronic reference}

James Bohman, «Institutional reform and democratic legitimacy: deliberative democracy and transnational constitutionalism », Revue européenne des sciences sociales [Online], XLV-136 | 2007, Online since 01 February 2010, connection on 19 April 2019. URL : http://journals.openedition.org/ ress/90; DOI : 10.4000/ress.90 
James BOHMAN

\section{INSTITUTIONAL REFORM AND DEMOCRATIC LEGITIMACY: DELIBERATIVE DEMOCRACY AND TRANSNATIONAL CONSTITUTIONALISM}

The European Union (EU), such as it is, remains the most developed project in transnational democracy. As a polity, it has progressed to the constitutional phase, in the sense that its democratic legitimacy has become an issue for public deliberation and popular ratification. The likely failure of its current constitutional proposal seems to many to be a stunning defeat for those who have taken up the cause of establishing democracy beyond the nation state. However important for emerging polities, constitutionalism is nonetheless only one aspect of democratic legitimacy (albeit one that is particularly important in an institutional structure as complex as the EU, which has grown by layers in different treaties). The need for democratic legitimacy was already explicitly recognized in the Maastricht Treaty, a central purpose of which was already to democratize the EU. However, some treaty provisions with this aim may have had unintended undemocratic consequences, such as making decision making less transparent. The impasse of the current constitutional convention shows the many difficulties and dilemmas that any polity inevitably confronts when creating legitimate institutions of democratic reform, all of which cumulatively lead to a potentially vicious circle: it is not democratic enough to propose the means and ends for achieving its own democratization.

Despite the seeming impasse that the failure to ratify the constitution may bring about, several different possibilities for democratization beyond the nation state remain open to the EU, each of which depends on a different understanding of the type of political body the EU is supposed to be. The most familiar option takes the EU to be a formal intergovernmental organization of states, by which the constitutionalism implicit in the treaties creates a normative framework for intergovernmental regulation for the sake of common interests. Here the parties to the constitution are member states, and thus the intergovernmental organizations that are established by the treaties have democratic legitimacy indirectly, through the delegation of state authority. In this constitutional context, the principal/citizen is empowered to demand greater transparency and accountability from the agent/organization, so that the focus of any process of democratic reform is found in determining the scope of delegated authority and in providing a clearer definition of the principals. This is certainly how citizens often try to influence international organizations such as NAFTA or the WTO, whose purposes are specific and functional rather than political. On the other hand, the EU has for more than a decade been shifting from its self-conception as an economic community with a common market, and is now engaging in polity building as a community of communities. The most significant marker of the success of transnational political 
legitimacy is the emergence of distinctly European citizenship with its own rights and powers, a significant step already taken in the 1993 Maastricht Treaty. In order to be distinctive, the normative powers of European citizens have to be at least potentially independent from their powers as citizens of individual member states. And yet, aside from lines at airports and judicial petitions, the benefits of European citizenship still pale in comparison to the rich array of rights and opportunities that have emerged from long historical struggles for democratic reform within states.

One of the central features of democratic constitutionalism is lacking in any such treaty-based understanding of the "material constitution» that effectively governs the European Union: namely, that «the People» can be the source of democratic renewal and change. Lacking a constitution to solve this problem, it is unclear how the EU can become more democratic, and can thus democratize itself to some degree, much less become a democracy. Since the EU is an unprecedented political community, questions about the nature of its future democracy remain open. What sort of democracy is suggested by some of the more novel aspects of the European integration? How can its deliberation be organized? Most of all, how can it creatively solve the problem of creating legitimate transnational institutions and methods for democratic reform, including, if necessary, a more democratic process of constitution making?

I begin my argument about constitutionalism beyond the nation state by discussing three necessary conditions for legitimate institutions for reform: these include formal, deliberative, and popular conditions. I argue that even in the absence of a fully constitutionalized condition for formal legitimacy, it is still possible for the European Union to initiate democratic reform processes that have deliberative and popular legitimacy. Second, I argue that the fundamental reflexive aim of the constitution itself as well as of the popular and deliberative processes of constitution making must be to create conditions of legitimate democratic reform. Central to the reform of the EU is the development of a more robustly deliberative citizenship, in which citizens have the minimum normative powers necessary for genuine democratization. Even if there are abundant reasons why the constitution should concern itself with problems of organizing democratic authority across the various levels and sites of political power and authority, these issues cannot be addressed until the vicious circle of the democratic illegitimacy of the European Union is overcome. Finally, in dealing with this second issue, I suggest some ways in which these deliberative and popular deficits can be overcome with respect to the process and aims of constitution making itself.

Addressing such procedural issues is not yet sufficient to understand the problems of democratizing the transnational polity. For this reason, it is first necessary to reach an understanding of the specific problem that a transnational constitution is supposed to solve: the republican problem of nondomination. Attending to the lack of democratic legitimacy and the related increased potential for domination by transnational institutions might help in understanding the democratically motivated discontent felt by many citizens within the EU. Before making specific proposals concerning the provisions of a transnational constitution, however, the novelty of this polity makes it necessary to reconstruct the European Union as an ideal type, in order to show just where such problems of domination might occur 
and what resources exist for addressing them in innovative practices and institutions, which resources may themselves be useful in organizing legitimate processes of constitutional reform in a transnational rather than merely a national manner. Above all, democratization requires new popular and deliberative processes. If you want to reform a transnational polity, you have to ask the right people under the right description, as having normative powers to establish their own duties and obligations. Getting this type of democratic reform off the ground requires some formal legitimacy, even if the formal conditions are themselves the objects of change.

\section{DEMOCRATICALLY LEGITIMATE REFORM}

In the existing structure of the European Union, power of initiative is shared by the member states through the Council. That is, such a power resides in the executive branch, with a procedure for its being carried out by a mixed body. For this reason, the 1994 constitutional proposal is a product of the current treaty structure, and inherits all of its problems of democratic legitimacy. I do not consider other possible sources of legitimacy, such as problem solving capacity or effectiveness emphasized by Fritz Scharf as «outcome legitimacy» ${ }^{1}$. In most constitutional democracies, there are three different aspects of democratic legitimacy, broadly understood, that play the role of legitimating democratic reforms. I will illustrate each of these aspects of legitimate democracy reform through processes that are part of constitution making or constitutional change. The formal legitimacy of any process of reform is found in the institutional authority to initiate it, through specified in the amendment procedure of a constitution or the authority structure of an organization that permits change. Popular legitimacy is found to the extent that the People have genuine opportunities to shape or assent to such reform, minimally the popular ratification of proposed changes or amendment, and that these opportunity are common knowledge among citizens. Popular legitimacy has a belief component, but is not reducible to citizens' pro or con attitudes. Finally, democratic reform has deliberative legitimacy, to the extent that the deliberative process of citizens offering reasons to each other in mutual justification plays some role, such as an influence over the process of drafting of the constitution or parts of a constitution. Deliberative legitimacy is usually measured by the quality of deliberation: that is, either by qualities such as the freedom, openness or publicity of the deliberative process, or by the quality of the reasons or outcomes, as measured by some independent standard. While the latter, more epistemic standard is preferred in some forms of inquiry, it is unlikely that a constitutional proposal can be settled by appeal to some procedure-independent standard.

It is now clear that the proposed EU constitution has little more than formal legitimacy, especially since the process of its formation lacked any genuinely deliberative and popular features. Its deliberative resources were internal to the body that was formed by the Council and thus only served to increase the popular

1 See Fritz Scharf, Governing in Europe: Effective or Democratic (Oxford, Oxford University Press, 1999). 
sense of illegitimacy. We might get the same result in Canada or the United States if proposed changes to the formal structure of NAFTA were put up for a vote, since NAFTA more clearly than the EU lacks the resources to reform itself democratically (given that its formal legitimacy could be met by the bylaws of the organization and its deliberative legitimacy refers to panels of experts as the subjects of deliberation). But such merely formal legitimacy is not yet democratic, precisely because it does not require that the opinions and interests of those outside the formally named bodies need to be heard and addressed. In fact, no one except these formally designated members has any legitimate say in the process of proposing such reforms, except in the ratification phase. Above all, the current constitution codifies rather than improves the status quo and thus does not respond to the popular dissatisfaction with the current EU structure.

The problem goes even deeper for the EU, since there is no «People» (yet) that it is organizing institutionally, but rather it has the stated overarching purpose of «bringing the peoples of Europe together in a closer Union». The «peoples» that were to ratify the treaty were the national publics, not the citizens of Europe. When put to a vote to ask these peoples as citizens of member states, the publics of France and the Netherlands rejected the democratic legitimacy of this constitution as a democratic reform. The purpose of the democratic reform would be to address the issue of the potential losses of freedom from domination in a polity in which the political subject of democracy is plural, demoi rather than a demos ${ }^{2}$. This attempt to create a democracy of demoi may seem paradoxical if citizens are to achieve the ideal of self-rule by becoming both authors and subjects of the laws of Europe ${ }^{3}$. Yet, as Bruce Ackerman has pointed out against such a «monistic» interpretation of constitutional structures, there is no one privileged place in which the popular will is located by some naïve synecdoche that takes the part for the whole. The EU has no legislative body, since its Parliament does not have the authority to enact the law directly. The only solution is, then, as Henry Richardson has put it, to look for a way in which «the processes that form the popular will can be distributed across the various parts of the constitutional structure ${ }^{4}$. The difficulty here is that in the case of the European Union, it is the executive power of the Council, as empowered in the 1993 Laeken Declaration that has the legitimate right to make such a proposal, independently of any exercise of the popular will. But if citizens are to be engaged both as citizens of Europe and of the member states, their will must be engaged at various stages and locations in the process.

For all the difficulties of formal legitimacy in the EU, the initiative of executive power need not exclude popular legitimacy. Here we might think of other institutions of legitimate democratic reform. For example, a Citizens' Assembly was empowered by the Premier of British Columbia to make a specific proposal for the reform of the province's electoral system as the result of internal processes

2 On this point, see James Bohman, «From Demos to Demoi: Democracy Across Borders», Ratio Juris 18:3 (2005), 293-314.

3 Jürgen Habermas, «Why Europe Needs a Constitution», New Left Review (2001), 11: 5-26.

4 For one version of such a view, see Henry Richardson, Democratic Autonomy (Oxford: Oxford University Press, 2002), 70. Besides distributive views, Habermas' arguments for «decentered» processes of will formation offer another alternative to the requirement of a unified democratic will. 
of deliberation among the randomly chosen ordinary citizens who made up the Assembly. Seen as a product of delegated executive power, something more than the transfer of normative powers is required for the Assembly to acquire fuller popular democratic legitimacy: namely, that the transparent process of its construction make it a minipublic in Archon Fung's terms ${ }^{5}$. As a minipublic, the Assembly used its delegated power by deliberating as citizen-representatives on behalf of the people, whose will could best be formed under the more ideal conditions that were fulfilled in the Assembly's deliberation (especially considering the complexities of various voting systems). The legitimating potential of such empowered participation in this case did not reside in the mere fact that the selection process somehow mirrored the wider public, but rather in the way in which the Assembly's judgment helps to shape public judgment about reform processes in some normative sense - as the opinion that the public ought to hold. The force of such a claim must be tested when the powers of the Assembly are transferred back to the public as a whole. In order to secure popular as well as deliberative legitimacy, the Assembly's proposal had to be voted upon by all citizens. Nonetheless, the direct participation of citizens in the proposal stage permits many citizens to already recognize its popular legitimacy even if the collective body of citizens was not actually present in deliberation. If this kind of procedure were repeated in various states or locations throughout the European Union, then it would not be paradoxical at all that the proposal voted upon would have some kind of popular credentials and thus increased democratic legitimacy.

In order to understand popular legitimacy democratically, however, more needs to be said about how such delegated exercises of citizens' powers are consistent with popular rule understood distributively. Here we may appeal to some idea of minimum popular democratic legitimacy, or more simply to the democratic minimum that makes citizens the sources of authority. Citizens would have to deliberate by employing just these shared normative powers ascribed to them in virtue of being citizens, and not merely those specific powers delegated to them by the Council's executive power. The Council itself, which delegated its powers to an intergovernmental body of representatives of heads of state and national parliaments with no mechanisms for popular consultation, produced the current proposal. Thus, the source of the legitimacy of the proposal is merely intergovernmental, and its deliberations did not carry with them deliberative or popular legitimacy accorded by the direct or indirect deliberation of citizens at large. Having no sense of the popular legitimacy of the constitution making process, the populus asserted its normative powers and exercised its freedom by saying «no» when they lacked no other power.

The democratic minimum requires more of legitimate authority than that it simply grant the permission to be consulted (here by a body of citizens that such an authority created). The inadequacy of consultation without empowerment can in fact be seen through the classical republican contrast between citizen and slave. Unlike slaves, citizens have the shared ability to initiate deliberation; this entails the ability not just to have officials or rulers respond to their interests, but also to

See Archon Fung, «Recipes for Public Spheres», The Journal of Political Philosophy 3 (2003), 338-367. 
set the items on an agenda and thus to be secure in their freedom from domination. As Arendt put it: «Beginning, before it becomes an historical event, is the supreme human capacity; politically, it is identical with human freedom. ${ }^{6}{ }^{6}$ This capacity marks the specific democratic contrast between citizen and slave, between having distinctively political rights that entail normative powers to do certain things and the inability to participate effectively in the absence of such powers. As Isaiah Berlin noted, this is true even if the master is an enlightened, liberal-minded despot or Rousseauian lawgiver who may permit a large measure of personal freedom, since whatever freedoms are granted to the slave, she remains dominated and thus lacks any intrinsic normative authority (or powers) even over herself; at best, she may only respond to the initiatives of others. Thus, the capacity to begin, rather than permission to be consulted or even given opportunities for contestation, provides the basic measure for the normative status of persons required for the democratic minimum.

Consider two alternative accounts. Both Philip Pettit's account of tracking and Allen Buchanan's interpretation of accountability and human rights offer more minimal views of the democratic minimum. Both might object that in order to have the minimum of democratic legitimacy one does not have to be able to initiate deliberation so much as to hold those who do deliberate accountable. According to Pettit, assemblies and minipublics are justified for being better able to «track» the «public good» of citizens than officials, where the democratic minimum is understood here in objectivist terms as something that officials can fail to track correctly for epistemic reasons ${ }^{7}$. Domination, however, is not merely due to epistemic failures, but is more a matter of who is entitled to offer interpretations of the public's good. Moreover, it would be equally wrong to say that deliberative assemblies must merely track, but rather also serve to form the popular will (rather than be ruled by the reasoning of others). In Buchanan's perhaps more modest alternative, the democratic minimum is related to accountability, which, he writes, is achieved by attaining the right combination of «representative institutions that most reliably achieve the accountability necessary for protecting basic human rights» ${ }^{8}$. While desirable in itself, such accountability and the formal legitimacy it would entail need not be the specific goal of a new constitution, since it is not clear that strengthening the powers of representatives in the European Parliament by itself would be sufficient to gain much popular or deliberative legitimacy. Neither Pettit nor Buchanan succeeds in defining the minimum so that it is sufficiently fine-grained, prospective, and open to placing second-order questions about institutions and procedural justice on the democratic agenda. Satisfying these demands requires that such political rights and the powers of citizens function as the mediating terms between democracy and justice.

In order to develop the virtues of this particular republican account, the democratic threshold of «freedom as the capacity to begin» can be further operationalized in two ways: first, in terms of the capacity of citizens to amend the basic nor-

6 Hannah Arendt, Origins of Totalitarianism (New York, Harcourt Brace, 1976), 479.

7 See Philip Pettit, Republicanism (Oxford, Oxford University Press, 1998), 88ff.

8 See Allen Buchanan, Justice, Legitimacy and Self-Determination (Oxford, Oxford University Press, 2004), ch. 3. 
mative framework, that is, the power to change the ways in which rights and duties are assigned; and second, in terms of the capacity of citizens to set an item on an open agenda, and thus to initiate joint, public deliberation. The first problem is solved via constitutionalism, in the broad sense of the term. A political order meets the democratic minimum in the first case only if it is a suitably reflexive order. Instituting reflexive democratic powers over the agenda as one such normative power solves the second problem. Even with these powers in place, constitutions cannot guarantee that citizens are the fully self-determining authors of all their obligations. As a result, such capacity to initiate a challenge and reorder the legal order itself (including rights, duties, and boundaries) is a necessary condition for nondomination. The institution of these constitutional features of democratic reflexivity is not an apparent goal of the EU draft convention, and the goal of democratization in the treaties is the limited condition of transparency.

In both these respects, a more reflexively democratic constitution gives citizens normative powers over normative powers, and political rights that include the power to change the assignment of rights and duties. However, it may be necessary to develop new institutions and forums for deliberation for this to be possible. More specifically, greater institutional differentiation and new normative powers may be necessary when the existing forms of will formation do not succeed in creating the proper distributive conditions for forming a popular will. Only in virtue of participating in forming such a popular will are citizens able to see the constitution as democratic rather than as arbitrarily imposed. Once initiated, the capacity of citizens to deliberate about the terms of democratic governance, including the rights, duties and powers of citizenship, constitutes a source of democratic legitimacy: the popular legitimacy provided by the opportunity and the capacity of citizens to exercise their freedoms, and then to decide upon and authoritatively enact such reform, since this is what explains the value of ratification votes. The democratic minimum, rather than the veto exercised in voting, is the source of distributed popular legitimacy.

Even with this increased overall democratic legitimacy, citizens may still decide that the constitutional proposals for reform lack deliberative legitimacy for procedural reasons. Considered more fully, the claim to deliberative legitimacy is much stronger than popular legitimacy as such: namely, that if other citizens underwent a similar process, they too would arrive at a similar reasoned judgment, and that this fact is manifest to other citizens in the deliberative role. Thus, the judgment is not only for reasons that they could accept, but also for reasons that they could accept owing specifically to the recognition of the deliberative legitimacy of the minipublic that proposes the changes. The internal deliberative legitimacy achieved procedurally among participants does not automatically extend to those who have not participated in it. It is clear then that the procedures used to increase the deliberative legitimacy of democratic reform may fail to attain the proper threshold of popular legitimacy and are furthermore subject to the same sort of veto.

By putting all these aspects of legitimacy together, we get a much more complex and demanding picture of democratic reform. This process is often complex and unsuccessful even in normal politics, which is distributed in deliberations and votes in a legislative body, approval and testing by courts and the executive, and administrative implementation. In the case of democratic and constitutional 
reform, the process is even more protracted and requires many different steps, but it can issue in a popular will to change those very institutions that have not yet formed a popular will. In the end, formal, popular and deliberative legitimacy should be manifested at various locations and stages of the process (even if in the case of democratically illegitimate institutions reform can be initiated without any formal legitimacy whatsoever). In this sense, Rousseau is right that popular sovereignty should not be alienated into any particular deliberative body or institutional location but distributed across the whole constitutional structure and extended across long periods of will formation.

The power of initiative possessed by all citizens who participate in deliberation is crucial for judging the deliberative legitimacy of the results. While the attempt to make a minipublic or popular assembly duly and descriptively representative seems to be an appropriate goal in the case of constructing a minipublic for electoral reform, the distributed character of institutions of democratic change lessens the legitimating significance of representativeness. Once deliberation begins, issues such as procedural openness and the availability of a proper set of alternative proposals play a more direct role. One consequence of this complex process is that in cases of democratic reform, deliberation is historically extended, sometimes for decades, as the popular will is still being formed. At the very least, that is what the negative results of the current referenda indicate. In cases of conflict, citizens look to the quality and responsiveness of the process of deliberation to ensure that the addressees of the justification have been able to shape the discussion and its outcome in relevant ways.

This leads to the general conclusion that I want to draw from this section. The popular will that legitimates the reform itself could only be formed if the process of constitution making and ratification already had all the hallmarks of legitimate institutions of democratic reform. In the case of the European Union, the process must not only be formally, popularly and deliberatively legitimate, it must also have an added feature: it must to some degree instantiate the requirements of legitimacy of the kind of democracy that it is meant to institute. It could well be constitutionally legitimate when judged post facto. For that reason, it must distribute the popular will in a way that is appropriate to the type of transnational polity that it is, rather than by a process that is based upon an interpretation of its legitimacy as an intergovernmental body that is many degrees of delegation removed from democratic sources of political authority ${ }^{9}$. This reflexivity is a further feature of legitimate institutions of democratic reform. Above all, for transnational polities such as the EU, the body of citizens or officials that proposes the new constitution must be transnational and not intergovernmental.

\section{DEMOCRATIC LEGITIMACY: RECONSTRUCTING THE IDEAL TYPE OF A TRANSNATIONAL POLITY}

9 Robert Dahl, «Can International Organizations Be Democratic? A Skeptic's View», in Democracy's Edges, C. Hacker-Cordon and I. Shapiro (eds.), (Cambridge, Cambridge University Press, 1999), 19-37. 
In the last section, I argued that the democratic core of constitutionalism is tied to its reflexive character, that is, to its capacity to make the basis of democracy itself the subject of the democratic deliberation of citizens. Such a self-transformative polity requires that a constitution enable its citizens to have just this normative power, a power that can be exercised in the capability to initiate deliberation that may change the terms of democratic cooperation. If the institutional structure is large and multileveled (as the EU's surely is), then this power must be present not merely in its legislative and parliamentary core, but must also be distributed throughout its various levels and dispersed sites of deliberation. From the criterion of nondomination implied by the democratic minimum, it also follows that some distinctly transnational form of federalism is the proper general type of institutional design, provided that it could be shown to be adequate to the democratic minimum with respect to the imposition of order and the possibilities of popular control. It also follows that the democratic deficit of the EU is in the case of democratic reform more properly a «deliberation deficit» that also leads to a «popular deficit».

Some have argued that deliberative legitimacy is local, rising to no higher level that that of a nation state ${ }^{10}$. Properly organized with dispersed power, however, large and numerous units also have deliberative advantages. At least some existing practices of the EU employ particular institutional structures of cooperation to take advantage of the dispersal of power and deliberation in multi-leveled and polycentric polities. These diverse and dispersed structures could be (or become) democratic insofar as they are constitutional orders that provide for deliberation about the proper location for any political deliberation and authorization. Without allowing for access to political influence over just such decisions, larger democracies have the potential for dominating smaller ones in transnational polities. Republican constitutional arguments for the separation of powers within the state can then be used against classical modern sovereignty, so that republican cosmopolitan institutions ought to further separate powers by disaggregating state monopolies and functions into a variety of institutional levels and locations as well as by disaggregating centralized transnational powers and redistributing them to citizens and opening them up to their deliberation.

One clear instance of this constitutionalism is implicit in the institutionalization of human rights in the European Convention for the Protection of Human Rights and the recent Charter of Rights. What is the purpose of this new layer of human rights enforcement beyond that already provided by the constitutions of member states? With the accompanying supranational European Court of Human Rights that grants rights of individual petition, there are (at least in the juridical dimension) multiple new institutions and memberships that can be invoked in making claims about human rights. Such overlapping differentiated and polyarchical structures permit greater realization of these rights and their claims against domination, as the citizens of demoi exercise the various entitlements gained from their overlapping memberships. In such a structure, human rights are constitutive of membership in a plural democratic polity and become a secure

10 As argued by both Will Kymlicka and Robert Dahl in their contributions to Democracy's Edges.

11 See Jo Shaw, «The Interpretation of European Citizenship», The Modern Law Review 40 
basis on which to assess new governance institutions procedurally, including, for example, the transparency of committees and the broad inclusion of participants in deliberations related to committees and methods of policy coordination. Even without any police powers, such differentiated institutions best realize rights in multiple demoi with diverse entitlements rather than in a single form of citizenship that uniquely constitutes the demos. Notice also that the explicit constitutionalism of the enumerated rights of the Charter promotes this kind of democratic structure, especially in the ways in which the Charter asserts the legal supremacy of the content of human rights at all levels.

How do multiple levels and sites promote the democratic minimum, and especially its central normative power of initiating deliberation about claims to justice? We can answer this question in two ways. One way is to see how the institutional design and practices of the EU could be used to promote this fundamental normative power, the power that is basic to the right to have rights. The EU could do so by providing a variety of locations and sites for deliberation in which publics interact with institutional powers and authorities. This division of powers could not be exclusively territorial or else it would be indistinguishable from a large nation state. The second way to promote deliberation follows from these features. To achieve more robust interaction across various levels and diverse locales and to promote citizens' capacity to initiate deliberation at multiple levels, large federalist institutions require a written constitution. If the EU is already wellordered and institutionally thick, then a new federalism need not reorganize institutions as much as settle the specific constitutional question: how is it that this structure can be sufficiently reflexive so as to make it democratic in the sense that issues of the nature of the polity, of rights and duties, must pass through the public deliberation of all its citizens?

Given the shape of the political institutions of the European polity, most cosmopolitans argue that the first step towards a supranational democratic order is to create a more effective and empowered European Parliament (EP), perhaps with a bicameral structure. The point here is not to see the EP as some privileged source of democratic legitimacy but as one of the locations for distributing deliberative and popular powers. This would clearly shift the location of various normative powers in Community institutions - including the rights to initiate legislation, to set directives and objectives for administrative bodies, and to review implementation in conjunction with the Commission - from the Council to the people. As an elected body, the EP can potentially represent and empower more diverse interests. With the general weakening of legislative bodies now found in many large nation states, however, it is unclear whether such a body would in fact overcome the gap between European institutions and the interests of the citizens they supposedly represent. The problem is not that the traditional separation of powers in federal constitutions would too radically alter the current shape of the EU, but that such a separation now needs to be understood in terms of a plurality of overlapping processes of distributed will formation ${ }^{11}$.

(1999), 293-317.

12 Michael Dorf and Charles Sabel, «The Constitution of Democratic Experimentalism», Colum- 
While the current draft constitution does indeed support greater parliamentary powers (including new powers of legislative and policy initiative), it is unclear whether introducing a further source of legislative initiative is really so problematic in a structure that already has several, and needs them in order to promote a thickly institutionalized democratic minimum. So long as the EP is not the sole source of legislative legitimacy, a new constitutional right to be included among these institutional bodies able to initiate policy debates could function as one among many mechanisms for public influence and accountability. It could do so in virtue of its tiered structure, which has the advantages of large and numerous legislatures that permit the emergence of a forum in which many diverse cultural and social perspectives are gathered. By reforming the EP with greater powers of initiative, the public spheres with which it interacts thereby acquire greater access to influence necessary for the constructive use of their communicative freedom in defining the terms of debate and deliberation. This proposal thus helps the EU meet the democratic minimum, if only with indirect legitimacy.

Nonetheless, simply giving the EP greater powers is insufficient to meet the democratic minimum for processes of democratic reform. Rather, more direct forms of public deliberation have emerged within the polyarchy of various procedures of responsive implementation of basic policies. This issue concerns the form of inquiry that institutions take to be necessary to inform their decision-making processes. As Charles Sabel and Joshua Cohen have argued, a «directly deliberative» design in many ways incorporates epistemic innovations and increased capabilities of economic organizations in the same way as, for instance, the New Deal institutions in the United States followed the innovations of industrial organization in the centralized mass production they attempted to administer and regulate $^{12}$. Roughly, such a directly deliberative form of organization uses nested and collaborative forms of decision-making based on highly collaborative processes of jointly defining problems and setting goals already typical in many large firms with dispersed sites of production. These forms of organization have been established in constitutional orders that do not require uniform policies, but permit a broad range of experimental initiatives, with public testing across levels and sites of mutual accountability and authority.

Given these requirements necessary for plural and dispersed polities, directly deliberative designs have a new salience, which is perhaps surprising only in light of previous turns toward centralization as solutions to problems of scale. Nondomination requires yet a different strategy, and I have already discussed the ways in which distributive publics or minipublics open up new directly deliberative possibilities for reform. Here we can see directly deliberative deigns as a way of producing distributed rather than plebescitory or «mass» popular legitimacy, the legitimacy to vote either yes or no in a referendum on some democratic reform and to participate in a mass public that is persuaded by various appeals for its loyalty. Such mass publics are particularly important in saying no to inadequate or self-defeating democratic reforms that do not increase overall democratic legitimacy. We might think of these mass publics as mobilized when the issues of reform reach a broad enough audience to give them the popular salience that they

bia Law Review 1 (1996), $292 \mathrm{ff}$.

${ }^{13}$ See Charles Sabel and Joshua Cohen, «Sovereignty and Solidarity: EU and US», in Governing 
lacked. However, such publics at best capture de facto public opinion and should best be seen as indicating that the popular will lacked sufficiently opportunities to be formed more fully and deliberatively.

In the European context, this deliberative design is often considered to be a form of rule by committee, or "comitology», with deliberative features. Under the current institutional structure and its Community Method, the power to initiate such policy coordination and testing lies solely with the Council. While not yet democratic, they can become a structural model of practices of inquiry for democratic reform. This mode of inquiry is explicitly recognized by the 2004 Convention in Article III, although none of its practices, such as the Open Method of Coordination (OMC) discussed below, are specifically named (Articles III-107, $148,179,180)$, and the powers of initiative and of policy coordination are still currently left entirely with the Commission ${ }^{13}$. Distributing such powers to a single location rather than across multiple levels and sites in the overall structure violates the basic institutional principle of republican federalism that powers ought to be widely distributed and iterated at various levels. At present, they lack the deliberative and popular legitimacy that would be necessary to make them useful ways of organizing a reflective equilibrium among competing public proposals.

The biggest difference between the EU and such delegative institutions as the WTO is precisely that the EU is itself a polity and thus already has a constitutional framework for accountability through open and multiperspectival deliberative inquiry. The EU's explicit recognition of political rights as human rights empowers those affected by authoritative decisions with normative powers, including rights of participation. This makes it possible for citizens of the EU to make claims rather than simply challenge decisions; that is, they may appeal not only to basic principles of democracy and human rights, but also to political institutions that should be responsive to their claims, and to a political community beyond that constituted by some specific functional task or treaty provision.

Constitutionalism also has another wider and more important role, to the extent that it is internalized in deliberative institutions: not only does it create some broad institutional distinctions between good and bad reasons; it also creates the demand for reflective equilibrium in decision making. Such equilibrium is necessary because norms of deliberation are part of the normative framework of inquiry into possible institutional reforms, so that at the very least actors are constrained to show the coherence of specific norms and decisions involving basic

Work and Welfare in the New Economy: European and American Experiments, J. Zeitlin and D. Trubek eds. (Oxford: Oxford University Press, 2003), 345-375. For directly deliberative arguments in favor of constitutionalizing the OMC, see Charles Sabel and Jonathan Zeitlin, «Active Welfare, Experimental Governance, Pragmatic Constitutionalism: The New Transformation of Europe», (unpublished manuscript) presented at the International Conference of the Hellenic Presidency of the European Union, «The Modernization of the European Social Model \& EU Policies and Instruments», Ioannina, Greece, 21-22 May, 2003. Here the point is to subject the OMC to the procedural requirements of «full blast» publicity. For a contrasting and more indirect view of the deliberative potential of the OMC, see Kerstin Jacobsson and Asa Vifell, «Integration by Deliberation? On the Role of Committees in the Open Method of Coordination», in European Governance, Deliberation, and the Quest for Democratization, E. Eriksen, C. Joerges, and Jürgen Neyer (eds.), (Oslo, ARENA, 2003), 411-451.

14 Jürgen Neyer, «Discourse and Order», Journal of Common Market Studies (2003), 41: 687706. 
norms. On the basis of this equilibrium effect of constitutionalization, Neyer argues that «noncompliance with the outcome of a deliberative procedure not only rejects the specific deal [that has been reached], but implicitly opposes the whole normative structure of which the specific norm is a part» ${ }^{14}$. To be truly democratic and reflexive, however, participants must be empowered to change the normative framework as well. Otherwise, constitutions would not have the resources to institute the requisite change within continuity that is necessary to retain their reflexive and polity-building roles.

By placing it in a normative and political framework, delegated authority is embedded in a polity and a reflexive legal order that constrains its exercise by empowering citizens to make legitimate claims independently of the particular epistemic community typically given such authority in functional organizations. However much such epistemic communities may constrain the exercise of authority and open decision-making processes to reflect exogenous influences, they filter such influences through their authoritative perspective, usually in order to reflect their current common theoretical commitments. Comitology goes a step further by embedding such deliberative processes in a wider set of political commitments and constraints of institutionalized interaction. Even if committees provide incentives for argumentation and reason giving rather than bargaining among institutional actors, they do not by themselves organize sufficient opportunities for empowered discursive interaction to be responsive to a wide range of influences and perspectives. Calls for greater transparency or for participation by civil society are not really the answer, however, since the weaknesses here are more structural. The transnational principle of institutional differentiation (rather than the simple separation of powers) calls for multiple and iterated processes within a revisable normative framework.

How do weaknesses in its deliberative institutions contribute to the EU's democratic deficit? Here the difficulty lies not with the breadth of its deliberative processes, but rather with their democratic depth. Even on the best interpretation offered by their defenders, committees currently function as forums for political processes and as coordinating bodies across various levels of governance; they are, however, deficient as argumentative forums to the extent that they are only «semi-public» and relate primarily to networks of administrative agencies and private policy experts ${ }^{15}$. A committee-based procedure, however deliberative, retains the weaknesses of the hierarchical relations of experts, officials and citizens within which it is embedded. In cases of democratic reform, a minipublic provides an institutionally constructed intermediary in popular will formation, although it could act in such as way as to become an agent for the creation of a larger public with normative powers.

Organized in this way, institutionalized deliberation becomes more responsive by virtue of strengthening and shortening the feedback loops necessary for imple-

\footnotetext{
15 See, for example, Christian Joerges and Jürgen Neyer, «From Intergovernmental Bargaining to Deliberative Political Processes: The Constitutionalization of Comitology», European Law Journal 3 (1997), 273-299.

${ }^{16}$ Frank Michelman, Brennan and the Supreme Court (Princeton, Princeton University Press, 2002), 59.

${ }^{17}$ Bruce Ackerman, We the People, Vol. 1 (Cambridge, Harvard University Press, 1991), ch. 1.
} 
mentation and learning in decentered, yet public decision making. Democracy could be deepened by such empowerment, and it could also be broadened by facilitating interaction between institutions and publics, especially if they institute something closer to what Frank Michelman calls the «full blast condition» for deliberation ${ }^{16}$. In other respects, the current constitutional moment is also an institutional learning process that is rather like the case of the New Deal-type reforms of the American nation state, motivated by both democratic and functional failures of its existing, not fully constitutionalized use of administrative and political power ${ }^{17}$. It might also permit the emergence of wider and deeper forms of deliberative interaction across institutions and demoi than have been realized thus far. Since deliberation in transnational polities does not aim at the same solutions to all problems, it requires only that EU-level institutions serve to establish the legitimate diversity, which would be constitutionalized in provisions related to the normative status of membership, with these in turn based on human rights. In order to institutionalize experimental practices, the constitution must reflect such a multilevel and federalist division of normative powers. Deliberative legitimacy is then tied directly to the presumption of plurality, which could be built into the constitution of a transnational democracy.

If the constitutional order helps build the polity, this leaves open an important question: who are the citizens of the Europolity? Given the new immigration in Europe, the public sphere is undergoing a different «structural transformation» with the potential for the domination of citizens over noncitizen residents and immigrants without the empowered participation and recognition of the latter as members of the public with communicative freedom ${ }^{18}$. The transformation of inquiry in the EU on the effects of policies on human rights and normative powers also depends on incorporating a cosmopolitan perspective of the Generalized Other into its public judgments and practices of assessment. The duties of EU citizens to the large numbers of noncitizens who reside in the EU include granting them some powers to influence deliberative processes, so that these remain democratically legitimate. With their commitments to human rights contained in the Charter of Rights explicitly constitutionalized, a more democratic EU would have greater constitutionally based obligations toward nonmembers, obligations that already exist in virtue of all residents of Europe having the normative powers that emerge from the commitments of a democracy of demoi.

Given the variety of constitutional moments in United States history that Ackerman discusses, it would be a mistake to see constitutional moments of «higher law making» in existing democratic polities as always emanating from the People. The lack of such a source in the case of the EU Convention is not exceptional, although the new proposal should the current one fail will likely go through some popular ratification procedure.

${ }^{18}$ The concept of a «structural transformation» is defined in this way by Habermas, The Structural Transformation of the Public Sphere (Cambridge: MIT Press, 1989). Habermas's writings on the EU surprisingly insist upon standard parliamentary institutions rather than upon exploring their potential structural transformation. My argument here is more consistent with his previous analyses of the legitimation crisis of the modern state.

19 Stephen Castles and M. J. Miller, The Age of Immigration (London, St. Martin's, 1999). 
This cosmopolitan perspective may also provide the impetus for ongoing collective learning at the constitutional level to go beyond some of the limits of the EU as a bounded community. For human political rights to be realized, the EU must be a community within a larger political community, a collection of demoi integrated as a larger democratic community. This transforms the problem of boundaries from an external to an internal one. With the recognition of the full range of human rights of all persons within a complex and differentiated institutional structure, the EU shifts from a regional to a cosmopolitan polity. Although the distributive publics and institutional deliberation can be iterated across regions as much as across states, this internalization of the perspective of the human political community provides the greatest potential for the democratization of the European polity. This requires a stronger and more demanding recognition of the right to nationality, with the danger that the failure to incorporate noncitizens «may lead to divided societies marked by severe inequalities and conflicts», including permanent minorities and excluded groups at the regional level ${ }^{19}$. Democracies with deep commitments to human rights have special obligations to humanity and thus to the nondomination of noncitizens in ways that nondemocratic polities to not. Such deep inequalities and conflicts also describe the source of the democratic deficit at the international level, and the failure of international institutions and forms of authority to incorporate the perspective of humanity. It is in this respect and not merely in its institutional structure and commitment to multilateral foreign policy that the EU could provide a model for transnational democratization. Without this cosmopolitan dimension, the constitutional framework would lack the universality to locate developing claims to rights of citizenship within a highly differentiated institutional order.

\section{CONCLUSION: RESOLVING THE PARADOX OF DEMOCRATIC REFORM}

If extending and deepening democracy are among the aims of the constitutional reform of the EU, it is easy to see why such a project is the continuation of what is best in the EU. In order to be democratic, the EU must not only achieve a democratic form of regional integration, it must also meet the repeated challenge of creating the conditions for democratic nondomination given the polity building of European integration. Given that meeting this challenge demands a transnational democratic minimum, the constitutional debates in the EU could well be a precursor to a process that is iterated in many different polities and many different institutions. From a constitutional perspective, the signal innovations of the EU could be given greater coherence by putting them in the service of realizing a democracy of demoi rather than in a single demos. Once the EU achieves a more fully reflexive order and a more differentiated institutional structure, the question shifts away from whether the EU is a democracy to how it can be more deliberatively and popularly legitimate. Such deliberation might be made more feasible if 
it were to attain greater popular legitimacy and more vibrant publics. The task of its reform is to create just these conditions.

A crucial claim of my argument is that the differentiated and deliberative processes that the new constitution would enable are at the same time the proper model for the constitution making process itself. Constitutional assemblies at least in part construct the public to whom they make a proposal to be ratified. While not a founding moment, these reforms should initiate a new phase in which the citizens of Europe begin the process of constructing institutions by which they govern themselves. If this is the problem that the constitution must solve, the first task that the Council should undertake is to empower the public to deliberate and propose some of the means to achieve these aims and democratic reforms.

Should the citizens of Europe create a new constitution? An affirmative answer implies that European integration has reached a more explicit and reflexive polity-building stage and that EU authority is willing to do more than just subject the results of their deliberation to the ratification according to the opinions of its mass publics. These citizens have judged and may well in the future continue to judge that the process lacks the legitimacy necessary for democratic reform. Democratic legitimacy across demoi is the work of generations and thus cannot be achieved simply by the act of writing and ratifying a constitution. A democratic constitution for Europe will not create a demos but it will create a basis for legitimate democratic reform that is currently lacking in the EU.

Saint-Louis University, Saint-Louis, Miss. 